\title{
Pemodelan Seasonal Autoregressive Integrated Moving Average Untuk Memprediksi Jumlah Kasus Covid-19 di Padang
}

\author{
Widdya Rahmalina ${ }^{1}$, Sari Puspita ${ }^{2}$ \\ ${ }^{1}$ Program Studi Pendidikan Matematika ,STKIP Adzkia \\ Jl. Taratak Paneh No.7 Korong Gadang, Kalumbuk, Kec. Kuranji, Kota Padang, \\ Sumatera Barat 25175 , Email: widdyarahmalina@stkipadzkia.ac.id \\ ${ }^{2}$ Program Studi Sistem Informasi, STMIK Indonesia Padang \\ Jl. Khatib Sulaiman No.1, Lolong Belanti, Kec. Padang Utara, Kota Padang, Sumatera \\ Barat 25136, Email: sari@stmikindonesia.ac.id
}

\begin{abstract}
Abstrak
Kota Padang pernah masuk dalam zona merah dan orange untuk penularan Covid19 selama beberapa bulan dikarenakan kurangnya kedisiplinan masyarakat dalam mematuhi protokol kesehatan. Adanya Laboratorium Rumah Sakit Universitas Andalas di Kota Padang yang memiliki alat untuk mengeluarkan hasil test SWAB juga mengakibatkan data diperoleh dengan cepat. Untuk memprediksi jumlah kasus baru pasien positif Covid-19, perlu dilakukan penelitian tentang peramalan. Salah satu metode yang dapat digunakan adalah metode Seasonal Autoregressive Integrated Moving Average atau disingkat SARIMA. Metode ini dipilih karena data menunjukkan pola seasonal mingguan. Data yang digunakan adalah data harian dari tanggal 2 Agustus 2020 sampai 6 Januari 2021 yang diperoleh dari Dinkes Kota Padang. Langkah-langkah yang dilakukan diantaranya uji stasioneritas, identifikasi model, estimasi parameter model, pemeriksaan diagnostic, dan terakhir pemilihan model terbaik. Hasil penelitian menunjukkan bahwa model SARIMA $(0,1,1)(0,1,1)^{7}$ merupakan model terbaik dengan estimasi parameter yang secara signifikan berbeda dengan nol, sehingga memenuhi asumsi white noise dengan nilai Means Squared Error sebesar 330.9333. Hasil peramalan untuk sebulan ke depan menunjukkan bahwa kasus pasien Covid-19 masih fluktuatif mulai dari 20 orang sampai 66 orang. Untuk itu diperlukan upaya dari pemerintah daerah Kota Padang dalam mendisiplinkan masyarakat agar kondisi Kota Padang dapat segera berubah menjadi zona hijau (aman) dari Covid-19.

Kata kunci: Covid-19, peramalan, SARIMA, Padang.
\end{abstract}

2000 Mathematics Subject Classification: $62 \mathrm{M} 10$

Submitted: 2021-02-12, Revisions Required: 2021-03-30, Accept Submission: 2021-05-29. 


\begin{abstract}
Seasonal Padang city has been in the red and orange zone against the transmission of the Covid-19 for several months due to the lack of community discipline in complying with health protocols. The existence of the Andalas University Hospital Laboratory in Padang City which has the tools to issue the SWAB test results also effect in data being obtained quickly. To predict the number of new cases of Covid-19 patients, research on forecasting is necessary. One method that can be used is the Seasonal Autoregressive Integrated Moving Average method or abbreviated as SARIMA. This method was chosen because the data shows a weekly seasonal pattern. The data used are daily data from 2 August 2020 to 6 January 2021 obtained from the Padang City Health Office. The steps taken include stationarity test, model identification, model parameter estimation, diagnostic examination, and finally selecting the best model. The results showed that the $\operatorname{SARIMA}(0,1,1)(0,1,1)^{7}$ model is the best model with parameter estimates that are significantly different from zero, so that it fulfills the white noise assumption with a Means Squared Error value of 330,9333. Forecasting results for the next month show that cases of Covid-19 patients are still fluctuating, ranging from 20 to 66 people. For this reason, efforts from the local government of the City of Padang are needed in disciplining the community so that the conditions of Padang City can immediately turn into a green (safe) zone from Covid-19.

Keywords: Covid-19, forecasting, SARIMA, Padang.
\end{abstract}

\title{
1. Pendahuluan
}

Covid-19 (Coronavirus Disease 2019) merupakan penyakit yang disebabkan oleh jenis Corona virus yaitu Sars-CoV-2 yang menyerang sistem pernapasan. Virus ini pertama kali ditemukan di Wuhan, China, pada bulan Desember 2019 dan mulai menyebar dengan cepat ke negara-negara lainnya, termasuk Indonesia. Luasnya penyebaran Covid-19 ke lebih dari 110 negara di dunia menyebabkan World Health Organization (WHO) secara resmi menyatakan Covid-19 sebagai pandemi pada tanggal 11 Maret 2019 (Azizah, [1]).

Kasus Covid-19 di Indonesia terus meningkat. Data worldmeters Corona per Kamis, 10 Desember 2020, menunjukkan bahwa Indonesia berada pada peringkat ke-19 tertinggi di dunia dan peringkat keempat Asia (Nagita, [6]). Sumatera Barat termasuk dalam 10 besar provinsi penyumbang kasus Covid-19 terbanyak di Indonesia selama 3 bulan berturut-turut dari bulan Desember sampai dengan Oktober 2020 (Shalihah, [11]). Kota Padang memiliki kasus positif tertinggi diantara kota-kota dan kabupaten lain di provinsi tersebut dan sempat berada pada zona merah dan zona orange selama beberapa bulan. Berdasarkan Langgam.id [9], pada bulan Oktober 2020, Kota Padang berada pada urutan ketujuh sebagai kabupaten dan kota dengan kasus aktif Covid-19 di Indonesia. Tingginya kasus positif Covid-19 di Kota Padang disebabkan oleh kurangnya kesadaran dan kedisiplinan masyarakat terhadap protokol kesehatan yang diterapkan oleh pemerintah. Tersedianya Laboratorium Rumah Sakit Universitas Andalas di Kota Padang sebagai laboratorium pemeriksaan Covid-19 di Indonesia memudahkan Dinas Kesehatan Kota Padang dalam melacak jumlah pasien yang terpapar Corona sehingga tidak heran jika dalam sehari terus terjadi penambahan kasus positif dari hasil uji labor tersebut. 
Untuk memprediksi jumlah kasus baru pasien positif Covid-19, perlu dilakukan penelitian tentang peramalan. Peramalan (forecasting) dilakukan untuk memprediksi suatu kejadian yang kemungkinan besar terjadi di masa yang akan datang. Hal ini dilakukan agar pihak yang berkepentingan dapat mengambil tindakan yang tepat terhadap kejadian tersebut. Data pasien Covid-19 merupakan data time series karena bergantung terhadap waktu. Untuk melakukan peramalan terhadap data time series terdapat beberapa metode yang bisa digunakan. Jika data yang diperoleh bersifat musiman, maka metode yang paling tepat adalah metode Seasonal Autoregressive Integrated Moving Average atau disingkat dengan SARIMA (Ukhra, [12]). SARIMA merupakan salah satu metode peramalan untuk data time series yang merupakan pengembangan dari metode ARIMA dikarenakan memiliki efek musiman (Wibowo, [13]). Metode SARIMA dipelajari secara mendalam oleh George Box dan Gwilym Jenkins dan terdiri dari empat tahap yaitu identifikasi, estimasi, pemeriksaan diagnostik dan peramalan (Makridakis et al, [5]). Metode SARIMA dibentuk oleh pola musiman atau Seasonal, Autoregressive (AR), Moving Average (MA) dan Integrated yang ditulis dalam bentuk $(p, d, q)(P, D, Q)^{S}$.

Beberapa penelitian yang membahas tentang peramalan jumlah kasus Covid-19 telah dibahas oleh beberapa peneliti, diantaranya adalah penelitian oleh Ariska dan Seftina [7] yang melakukan peramalan penyebaran jumlah kasus Covid-19 di Propinsi Jawa Tengah menggunakan metode ARIMA. Nurul Litha Sari [10] juga melakukan analisa perbandingan performa metode Simple Moving Average dan Exponential Moving Average untuk peramalan jumlah penderita Covid-19.

Dalam tulisan ini akan dibahas tentang bagaimana bentuk pemodelan jumlah kasus terkonfirmasi positif Covid-19 di Kota Padang yang digunakan untuk memprediksi jumlah kasus tersebut untuk sebulan ke depan. Metode yang digunakan adalah metode SARIMA dikarenakan data jumlah kasus terkonfirmasi positif Covid-19 mengandung pola musiman ( seasonal). Metode yang dipilih berbeda dengan penelitian Ariska dan Seftina yang memiliki data yang tidak mengandung pola musiman. Sedangkan penelitian yang dilakukan oleh Nurul Litha Sari memiliki pola data yang mendekati eksponensial. Oleh karena data penelitian ini mengandung pola musiman dan tidak mendekati eksponensial maka metode SARIMA sangat tepat untuk digunakan. Dengan adanya penelitian ini, diharapkan pihak-pihak terkait dapat melakukan beberapa tindakan yang tepat agar penyebaran virus ini dapat diatasi dengan baik.

\section{Metode Penelitian}

Penelitian ini menggunakan data sekunder yakni data harian jumlah kasus positif Covid19 yang tercatat dan dilaporkan di Dinas Kesehatan kota Padang [2] mulai dari 2 Agustus 2020 sampai 6 Januari 2021 atau sebanyak 158 titik historis. Teknik analisis data yang digunakan pada penelitian ini adalah metode Seasonal Autoregeressive Integrated Moving Average (SARIMA).

SARIMA memiliki bentuk umum sebagai berikut (Rahmalina dan Darfia, [8] :

$$
\phi_{b}(B) \Phi_{p}\left(B^{s}\right)(1-B)^{d}\left(1-B^{s}\right)^{D} X_{t}=\theta_{q}(B) \Theta_{Q}\left(B^{s}\right) e_{t}
$$




$$
\begin{aligned}
e_{t} & : \text { error } \\
X_{t} & : \text { Nilai Pengamatan pada waktu ke- } t(t=1,2, \ldots, n)
\end{aligned}
$$

$(1-B)^{d}$ : Operasi matematis dari differencing non musiman

$\left(1-B^{s}\right)^{D}$ : Operasi matematis dari differencing musiman

$$
\begin{aligned}
\phi_{P}(B) & : \text { Operator Autoregressive }=\left(1-\phi_{1} B-\phi_{2} B^{2}-\cdots-\phi_{P} B^{P}\right) \\
\Phi_{P}\left(B^{s}\right) & : \text { Operator Autoregresive Musiman }=\left(1-\phi_{1} B^{s}-\phi_{2} B^{2 s}-\cdots-\phi_{P} B^{P s}\right) \\
\theta_{q}(B) & : \text { Operator Moving Average }=\left(1+\theta_{1} B-\theta_{2} B^{2}-\cdots-\theta_{q} B^{q}\right) \\
\Theta_{Q}\left(B^{s}\right) & : \text { Operator Moving Average Musiman }=\left(1-\Theta_{1} B^{s}-\Theta_{2} B^{2 s}-\cdots-\Theta_{Q} B^{Q s}\right)
\end{aligned}
$$

Data yang diolah menggunakan metode SARIMA haruslah stasioner, untuk itu langkah pertama yang harus dilakukan adalah pengujian stasioneritas data yakni uji stasioner terhadap varians dengan transformasi Box-Cox dan uji stasioner terhadap mean dengan $A u g$ mented Dickey Fuller (Yaffee and McGee, [14]). Data yang tidak stasioner terhadap varian dan mean dapat distasionerkan dengan melakukan transformasi stabilitas varians dan proses differencing. Langkah kedua adalah mengidentifikasikan model sementara dari plot ACF dan PACF. Ketiga, estimasi parameter dari model yang telah dibentuk dengan mengecek nilai signifikansi parameter-parameter AR, MA, musiman dan non musiman berbeda dengan nol. Keempat, melakukan pemeriksaan diagnostic yakni error yang ada harus mengikuti proses white noise yakni error tidak berautokorelasi dengan melihat hasil uji Ljung-Box ( $p-$ value > alpha $=0.05)$ dan error berdistribusi normal dengan melihat hasil uji Kolmogorov Smirnov $(p-$ value $>$ alpha $=0.05)$ (Lestari dan Wahyuningsih, [4]). Kelima, pemilihan model terbaik dengan melihat nilai MS atau Means Square terkecil (Hadijah, [3]). Terakhir, data hasil ramalan dibandingkan dengan data aktual yang kemudian digambarkan dalam sebuah grafik.

\section{Hasil Dan Pembahasan}

Plot data harian jumlah pasien Covid-19 di kota Padang mulai dari 2 Agustus 2020 sampai 6 Januari 2021 dapat dilihat pada Gambar 1

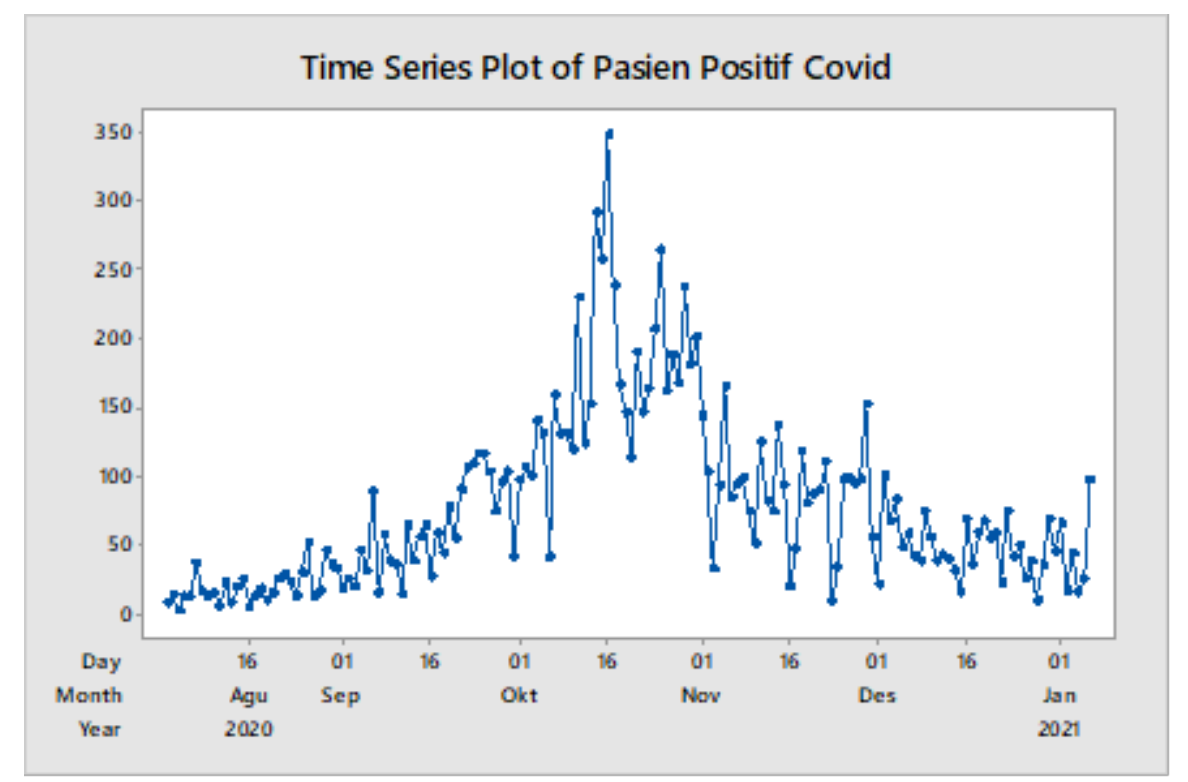

Gambar 1. Plot data pasien positif Covid-19 
Pada Gambar 1 dapat dilihat bahwa jumlah pasien positif Covid-19 tertinggi terjadi pada tanggal 16 Oktober 2020 sebanyak 347 kasus dan terendah terjadi pada tanggal 4 Agustus 2020 sebanyak 2 kasus. Selain itu, dapat dilihat bahwa plot data mengandung pola musiman sehingga digunakan metode SARIMA (Seasonal Autoregressive Integrated Moving Average). Plot data juga tidak berfluktuasi di sekitar garis yang sejajar sumbu waktu atau membentuk trend yang tidak datar pada sumbu horizontal sehingga dapat diasumsikan bahawa data belum stasioner terhadap mean. Plot data juga tersebar membangun pola melebar atau menyempit (bentuk terompet) sehingga dapat diasumsikan bahwa data belum stasioner terhadap varians. Untuk lebih memastikannya dilakukan uji stasioner data terhadap mean dan varians.

3.1. Kestasioneran. Untuk menguji kestasioneran data terhadap varians dapat dilakukan dengan uji transformasi Box-Cox. Data dikatakan sudah stasioner terhadap varians apabila hasil uji menyatakan nilai rounded value sama dengan 1.

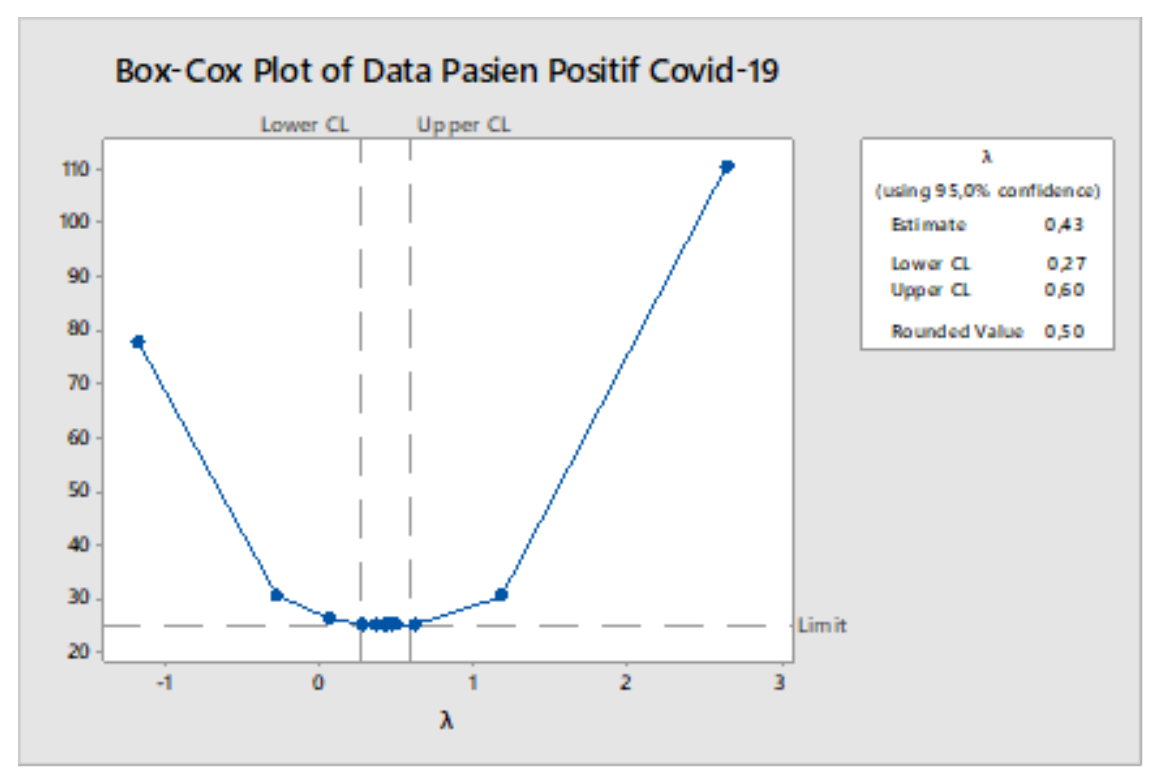

\section{Gambar 2. Plot Box-Cox}

Pada Gambar 2 dapat dilihat bahwa hasil uji transformasi Box-Cox diperoleh nilai rounded value adalah 0.5 , sehingga dapat disimpulkan bahwa data tidak stasioner terhadap varians, untuk itu perlu dilakukan transformasi data dalam bentuk akar kuadrat. Setelah dilakukan pemeriksaan kembali dengan uji transformasi Box-Cox diperoleh nilai rounded value sama dengan 1 sehingga data sudah stasioner terhadap varians. Untuk menguji kestasioneran data terhadap mean dilakukan uji Augmented Dickey Fuller atau sering dikenal dengan unit root test (uji akar unit). Dari hasil uji diperoleh nilai mutlak statistik-t ADF lebih kecil dari nilai mutlak statistik-t kritis (t-tabel) yakni $|-2.499695|<|-3,472813|$ dengan nilai probability $0.1175>0.05$, sehingga dapat disimpulkan bahwa data belum stasioner terhadap mean. Oleh karena itu, perlu dilakukan differencing (pembeda) denggan nilai $d=1$. Setelah itu dilakukan pengujian kembali dan diperoleh nilai mutlak statistik-t ADF lebih besar dari nilai mutlak statistik-t kritis (t-tabel) yakni $|-13.13586|>|-3.472813|$ dengan nilai probability $0.0000<0.05$, sehingga dapat disimpulkan bahwa data sudah stasioner terhadap mean. Selain itu, untuk menghilangkan kestasioneran data yang diakibatkan oleh pola seasonal dilakukan differencing seasonal sehingga orde $D=1$.

3.2. Identifikasi Model. Setelah data stasioner, langkah selanjutnya adalah identifikasi model sementara dengan melihat plot Autocorrelation Function (ACF) dan Partial Autocorrelation Function (PACF). 


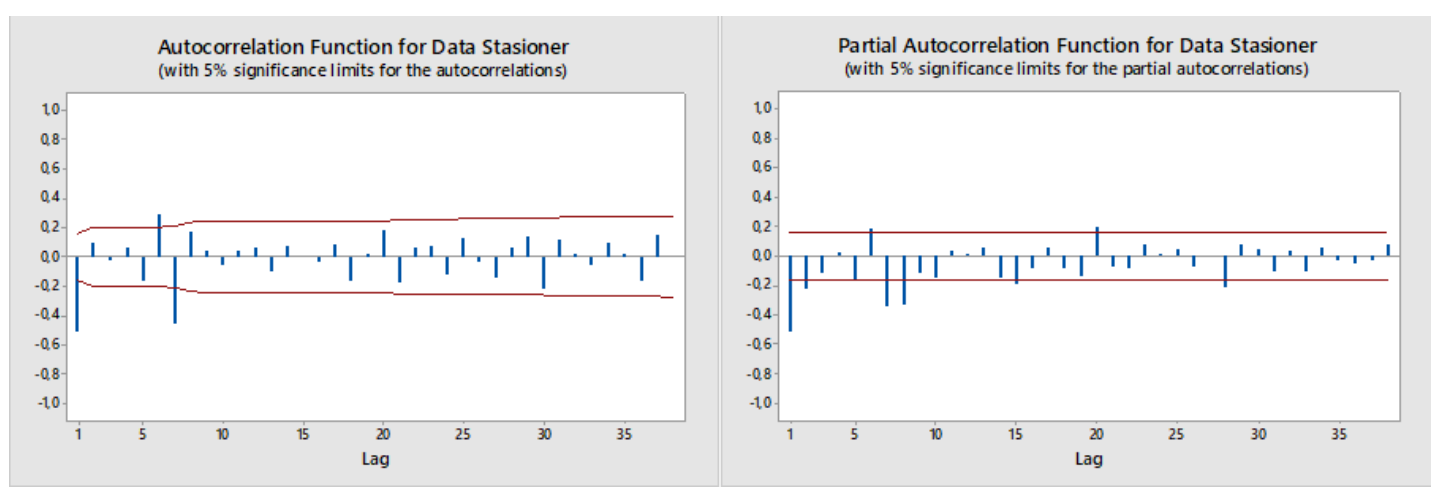

Gambar 3. Plot ACF dan PACF

Pada Gambar 3 dapat dilihat bahwa plot ACF bertipe dies down dan cutt off pada lag 1 dan lag 7 (lag 1 musiman). Begitu juga pada plot PACF bertipe dies down dan cutt off pada lag 2, sehingga identifikasi model sementara adalah $\operatorname{SARIMA}(0,1,1)(0,1,1)^{7}$, $\operatorname{SARIMA}(1,1,1)(0,1,1)^{7}$, dan $\operatorname{SARIMA}(2,1,1)(0,1,1)^{7}$.

3.3. Estimasi Parameter. Setelah identifikasi model sementara, maka langkah selanjutnya adalah estimasi parameter. Parameter-parameter yang secara signifikan berbeda dengan nol yang ada pada model menunjukkan suatu model yang baik. Hasil uji signifikansi dari parameterparameter dapat dilihat pada Tabel 1.

TABEL 1. Tabel uji signifikansi

\begin{tabular}{|c|c|c|c|c|c|}
\hline Model & Parameter & Koef & SE koef & P-value & Keputusan \\
\hline \multirow{2}{*}{ SARIMA $(0,1,1)(0,1,1)^{7}$} & MA 1 & 0.6880 & 0.0600 & 0.000 & Signifikan \\
\cline { 2 - 6 } & SMA 7 & 0.8551 & 0.0473 & 0.000 & Signifikan \\
\hline \multirow{3}{*}{ SARIMA $(1,1,1)(0,1,1)^{7}$} & AR 1 & -0.047 & 0.121 & 0.698 & Tidak Signifikan \\
\cline { 2 - 6 } & MA 1 & 0.6601 & 0.0904 & 0.000 & Signifikan \\
\cline { 2 - 6 } & SMA 7 & 0.8535 & 0.0476 & 0.000 & Signifikan \\
\hline \multirow{3}{*}{ SARIMA $(2,1,1)(0,1,1)^{7}$} & AR 1 & -1.5175 & 0.0723 & 0.000 & Signifikan \\
\cline { 2 - 6 } & AR 2 & -0.5264 & 0.0716 & 0.000 & Signifikan \\
\cline { 2 - 6 } & MA 1 & -0.995271 & 0.000012 & 0.000 & Signifikan \\
\cline { 2 - 6 } & SMA 7 & 0.8271 & 0.0495 & 0.000 & Signifikan \\
\hline
\end{tabular}

Pada Tabel 1 dapat dilihat model SARIMA $(0,1,1)(0,1,1)^{7}$ dan $\operatorname{SARIMA}(2,1,1)(0,1,1)^{7}$ mempunyai parameter-parameter yang signifikan berbeda dengan nol, dimana setiap parameter AR, MA, dan SMA memiliki nilai p-value $<0.05$. Sedangkan model SARIMA $(1,1,1)(0,1,1)^{7}$ memiliki parameter yang signifikan tidak berbeda dengan nol yakni parameter AR dengan nilai p-value $=0.698>0.005$. Sehingga dapat disimpulkan bahwa model-model yang baik serta dapat digunakan untuk tahapan selanjutnya adalah model $\operatorname{SARIMA}(0,1,1)(0,1,1)^{7}$ dan $\operatorname{SARIMA}(2,1,1)(0,1,1)^{7}$.

3.4. Pemeriksaan Diagnostik. Hal yang dilakukan pada tahapan ini yakni melihat apakah model yang dihasilkan sudah layak digunakan untuk peramalan atau belum, dengan melakukan pemeriksaan diagnostic yakni error yang ada harus mengikuti proses white noise yakni error tidak berautokorelasi (kerandoman)dan berdistribusi normal. Uji kerandoman error (residual) dilakukan dengan menggunakan uji L-jung Box yang dapat dilihat pada Tabel 2. 
TABEL 2. Output l-jung box

\begin{tabular}{|c|c|c|}
\hline \multirow{2}{*}{ Lag } & \multicolumn{2}{|c|}{$P-$ value } \\
\cline { 2 - 3 } & SARIMA $(0,1,1)(0,1,1)^{7}$ & SARIMA $(2,1,1)(0,1,1)^{7}$ \\
\hline 12 & 0.914 & 0.018 \\
\hline 24 & 0.887 & 0.056 \\
\hline 36 & 0.663 & 0.012 \\
\hline 48 & 0.827 & 0.037 \\
\hline
\end{tabular}

Pada Tabel 2 dapat dilihat bahwa model $\operatorname{SARIMA}(0,1,1)(0,1,1)^{7}$ di setiap lagnya pada output L-Jung Box memiliki nilai $p$-value $>0.05$, hal ini mengakibatkan residual dari model tersebut bersifat random atau tidak berautokorelasi sehingga layak digunakan untuk peramalan. Sedangkan model $\operatorname{SARIMA}(2,1,1)(0,1,1)^{7}$ pada lag 36 dan lag 48 masing-masing memiliki nilai $p$-value $=0.012<0.005$ dan $0.037<0.005$, sehingga residual tidak bersifat random (acak) atau saling berautokorelasi sehingga model tersebut tidak layak digunakan untuk peramalan. Pemeriksaan residual berdistribusi normal untuk model $\operatorname{SARIMA}(0,1,1)(0,1,1)^{7}$ dilakukan dengan uji normalitas Kolmogorov-Smirnov, dimana jika nilai $p$-value $>0.05$, maka residual berdistribusi normal.

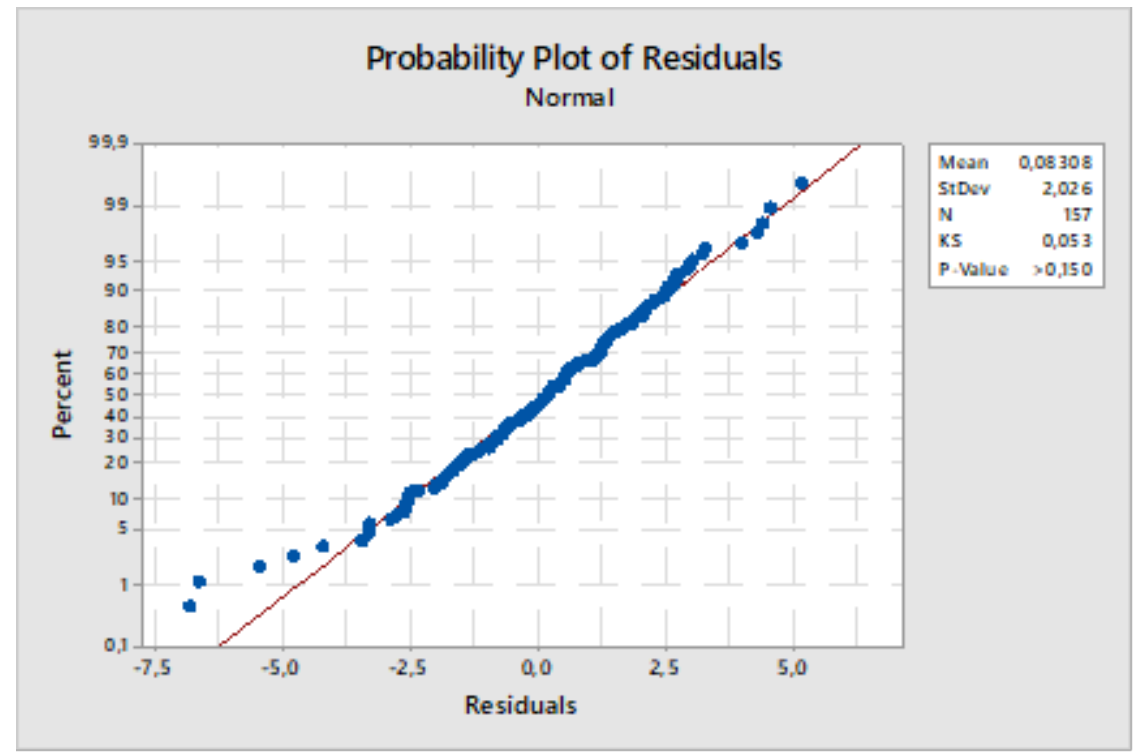

GAmbar 4. Plot residual model $\operatorname{SARIMA}(0,1,1)(0,1,1)^{7}$

Pada Gambar 4 dapat dilihat bahwa model SARIMA $(0,1,1)(0,1,1)^{7}$ memiliki residual dengan $p$-value $>0.150$ dan sebaran data residual berupa titik-titik biru menyebar di sepanjang garis normal, sehingga dapat disimpulkan bahwa residual model $\operatorname{SARIMA}(0,1,1)(0,1,1)^{7}$ berdistribusi normal. Dari kedua hasil uji L-Jung Box dan uji Kolmogorov-Smirnov dapat disimpulkan bahwa model SARIMA $(0,1,1)(0,1,1)^{7}$ layak digunakan untuk peramalan.

3.5. Peramalan. Model SARIMA $(0,1,1)(0,1,1)^{7}$ adalah satu-satunya model yang memenuhi uji signifikansi parameter dan uji white noise dimana residual model bersifat acak dan berdistribusi normal sehingga layak untuk meramalkan jumlah pasien Covid-19. Hasil peramalan dapat dilihat pada Tabel 3 . 
TABEL 3. Hasil ramalan jumlah pasien positif Covid-19

\begin{tabular}{|c|c|c|c|c|c|}
\hline Tanggal & Hasil Ramalan & Data Aktual & Tanggal & Hasil Ramalan & Data Aktual \\
\hline 7 Jan 2021 & 49 & 49 & 22 Jan 2021 & 49 & 38 \\
\hline 8 Jan 2021 & 53 & 71 & 23 Jan 2021 & 40 & 37 \\
\hline 9 Jan 2021 & 44 & 49 & 24 Jan 2021 & 47 & 26 \\
\hline 10 Jan 2021 & 52 & 0 & 25 Jan 2021 & 21 & 16 \\
\hline 11 Jan 2021 & 24 & 0 & 26 Jan 2021 & 20 & 7 \\
\hline 12 Jan 2021 & 23 & 23 & 27 Jan 2021 & 61 & 30 \\
\hline 13 Jan 2021 & 66 & 38 & 28 Jan 2021 & 42 & 31 \\
\hline 14 Jan 2021 & 47 & 63 & 29 Jan 2021 & 47 & 18 \\
\hline 15 Jan 2021 & 51 & 34 & 30 Jan 2021 & 38 & 28 \\
\hline 16 Jan 2021 & 42 & 31 & 31 Jan 2021 & 45 & 28 \\
\hline 17 Jan 2021 & 50 & 56 & 1 Feb 2021 & 20 & 14 \\
\hline 18 Jan 2021 & 23 & 13 & 2 Feb 2021 & 19 & 12 \\
\hline 19 Jan 2021 & 21 & 27 & 3 Feb 2021 & 59 & 49 \\
\hline 20 Jan 2021 & 63 & 40 & 4 Feb 2021 & 40 & 29 \\
\hline 21 Jan 2021 & 45 & 39 & 5 Feb 2021 & 45 & 18 \\
\hline
\end{tabular}

Pada Tabel 3 dapat dilihat bahwa menurut model untuk peramalan diperoleh jumlah pasien positif Covid-19 tertinggi pada bulan Januari adalah 66 pada tanggal 13 Januari 2021, sedangkan yang terendah adalah 20 yakni pada tanggal 26 Januari 2021 dan 1 Februari 2021. Sedangkan dari data aktual diperoleh jumlah pasien Covid-19 yang tertinggi pada tanggal 8 Januari 2021 sebanyak 71 orang dan tidak adanya pasien Covid-19 pada tanggal 10, 11 Januari 2021. Nilai Mean Squared Error dapat dihitung sebagai berikut :

$$
M S E=\frac{1}{n} \sum_{i=1}^{n}\left(Y_{i}^{\prime}-Y_{i}\right)^{2}=\frac{1}{30}(9928)=330,9333
$$

Plot data ramalan dan data aktual dapat dilihat pada Gambar 5.

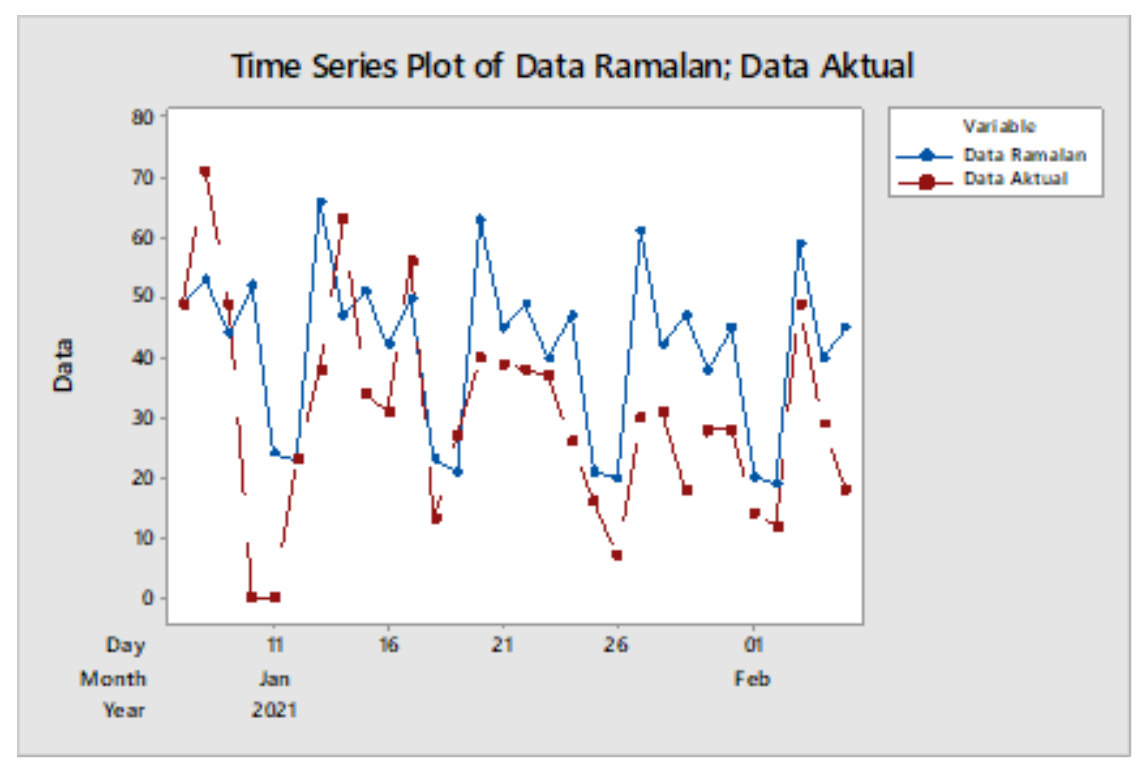

GAMBAR 5. Plot data ramalan dengan data aktual 
Pada Gambar 5 dapat dilihat bahwa plot data ramalan hampir mendekati plot data sebenarnya walaupun terdapat perbedaaan jauh pada tanggal 10-11 Januari dikarenakan data aktualnya bernilai 0 .

\section{Simpulan}

Untuk memprediksi jumlah pasien positif Covid-19 di Kota Padang dapat menggunakan pemodelan SARIMA $(0,1,1)(0,1,1)^{7}$ karena estimasi setiap parameternya berbeda dengan nol dan memenuhi asumsi white noise yakni residual model bersifat acak dan berdistribusi normal. Model ini memiliki nilai MSE sebesar 330.9333. Berdasarkan hasil prediksi jumlah pasien positif Covid-19 untuk sebulan ke depan masih mengalami fluktuatif dengan jumlah terbesar sebanyak 66 orang dan terendah 20 orang. Hal ini sangat bergantung dari upaya pemerintah Kota Padang dalam menanggulangi pandemi Covid-19 dan butuh kesadaran dari masyarakat dalam mematuhi protokol kesehatan dan menjalankan gaya hidup sehat agar terhindar dari virus Covid-19. Untuk pengembangan penelitian kedepannya, dapat menggunakan metode lain dengan mempertimbangkan faktor-faktor yang mempengaruhi jumlah pasien positif Covid-19. Selain itu, bisa juga menggunakan metode yang dapat memuat keseluruhan data karena data pada penelitian ini terbatas pada data yang tidak bernilai nol saja.

\section{DAFtar Pustaka}

[1] Azizah, K.N., 2021, WHO Resmi Nyatakan Virus Corona COVID-19 sebagai Pandemi, detikHealth, https : //health.detik.com/berita - detikhealth/d-4935355/who-resmi - nyatakan - virus - corona - covid19 - sebagai - pandemi on Januari 06, 2021.

[2] Dinkes Padang, 2021, Situasi Terkini Kasus Coronavirus Disease (COVID-19) di Kota Padang, https : //dinkes.padang.go.id/situasi - terkini - perkembangan - kasus - coronavirus - disease - covid - $19-$ di - kota - padang 6 - januari - 2021 - update - pukul - $1300-$ wib on Januari 06, 2021.

[3] Hadijah, H., 2013, Peramalan operasional reservasi dengan program minitab menggunakan ARIMA PT Surindo Andalan, The Winners, Volume 14, Nomor 1, Maret 2013, Pages 13-19.

[4] Lestari, N., Wahyuningsih, N., 2012, Peramalan kunjungan wisata dengan pendekatan model SARIMA (studi kasus: Kusuma Agrowisata), Jurnal Sains dan Seni ITS, Volume 1, Nomor 1, September 2012, Pages. 29-33.

[5] Makridakis, S., Wheelwright, S.C., and Hyndman, R.J., 1998, Forecasting: Methods and Apllication, John Wiley, New York.

[6] Nagita, N. S., 2021, Corona Dunia Tembus 70 Juta Kasus, Indonesia Kini Peringkat Berapa?, detikHealth, https : //health.detik.com/berita - detikhealth/d - 4935355/who-resmi-nyatakan - virus - corona covid - 19 - sebagai - pandemi on Januari 06, 2021.

[7] Rachmawati, A. K., 2020, Peramalan penyebaran jumlah kasus Covid19 provinsi Jawa Tengah dengan metode ARIMA, Zeta-Math Journal, Volume 6, Nomor 1, Desember 2020, Pages 11-16.

[8] Rahmalina, W, and Darfia, N.E., 2020, Peramalan indeks kekeringan Kelayang menggunakan metode SARIMA dan SPI, POTENSI : Jurnal Sipil Politeknik Volume 22, Nomor 1, Maret 2020, Pages 64-75.

[9] Redaksi, 2021, Padang Masuk 12 Besar Nasional Penyumbang Kasus Aktif Covid-19, https : //langgam.id/padang - masuk - 12 - besar - nasional - penyumbang - kasus - aktif - covid - 19/ on Januari 06, 2021.

[10] Sari, N.L., 2020, Analisis perbandingan performa metode Simple Moving Average dan Exponential Moving Average untuk peramalan jumlah penderita Covid-19, Indonesian Journal of Data and Science, Volume 1, Nomor 3, Desember 2020.

[11] Shalihah, N. F., 2021, 10 Provinsi dengan Penambahan Kasus Covid-19 Terbanyak 4 Bulan Terakhir, Mana Saja?, Kompas.com, https : //www.kompas.com/tren/read/2021/01/08/160500465/10-provinsidengan - penambahan - kasus - covid - 19 - terbanyak - 4 - bulan - terakhir on Januari 06, 2021.

[12] Ukhra, A.U., 2014, Pemodelan dan peramalan data deret waktu dengan metode Seasonal ARIMA, Jurnal Matematika UNAND, Volume 3, Nomor 3, Pages 59-67.

[13] Wibowo, A., 2018, Model peramalan indeks harga konsumen kota Palangka Raya menggunakan Seasonal ARIMA (SARIMA), Jurnal Matematika, Volume 17, Nomor 2, November 2018, Pages 1724.

[14] Yaffee, R.A., and McGee, M., 2000, An Introduction to Time Series Analysis and Forecasting: With Applications of $S A S$ and SPSS, Elsevier Science. 
